\title{
O morto anônimo e a máscara
}

\section{Marisa Flórido Cesar'}

Resumo: 0 artigo reflete sobre a morte anônima e a máscara, a partir de imagens, palavras e obras de arte que circularam pelas mídias e redes digitais ao longo da pandemia de covid-19.

Palavras-chave: Arte contemporânea. Máscara. Pandemia.

\section{The anonymous dead body and the mask}

\begin{abstract}
The article reflects on anonymous death and the mask, based on images, words and works of art that circulated through the media and digital networks throughout the pandemic.
\end{abstract}

Keywords: Contemporary art. Mask. Pandemic. 


\section{"Silêncio, estamos morrendo"}

Quando a frase foi pronunciada, era abril de 2020. Mal sabíamos que o terror se estenderia pelo ano seguinte. A morte banalizada, opacificada nas estatísticas diárias, contabilizaria, um ano depois, centenas de milhares de vidas perdidas neste país. A gestão desastrosa da pandemia, entre negacionismos e indiferença, nos arrastaria a um pacto cruel com a morte. A solidão da morte entre as máquinas, a asfixia do oxigênio que nos falta, a escassez dos medicamentos de sedação que aliviariam a dor só fazem agudizar o sentimento de nossa morte como coletividade. Quem esperava que o sentimento de fim, de catástrofe vivida por todos, convergisse nossa finitude individual e coletiva numa pertença comum e solidária, viu ruir suas expectativas ou promessas. Sem os rituais do luto, sem poder enterrar nossos mortos, quedamo-nos estupefatos ou insensíveis ao horror das imagens das milhares de covas rasas abertas na terra, que nos chegam pelas mídias e redes digitais. As vidas não enlutáveis, conformadas na clave da indiferenciação quantitativa, não recebem o lamento público por suas mortes. Prisioneiros de nosso torpor, assistimos à morte sem rosto, sem face, sem corpo.

A frase cintila escrita em branco, entre outras que emergem e naufragam em um fundo obscuro. Compõem uma constelação de vozes e palavras do vídeo Contágio de Regina de Paula, que ilustra a capa deste número da revista. Em 13 de abril de 2020, a artista lançaria uma chamada à sua rede de contatos, por meio do aplicativo WhatsApp, solicitando testemunhos sobre aquele momento de isolamento. "Os áudios recebidos de diversas cidades brasileiras deram origem a esse contágio de palavras e vozes", conta-nos. Tudo é dito e escrito na ausência da imagem, como se tramasse um embate entre o que desaparece mas insiste, entre o excesso de um evento traumático e extremo e a insuficiência de qualquer mostração ou narração. Algo inassimilável, que resiste a ser simbolizado, mas que não cessa de inscrever sua não inscrição.

O silêncio clamado era, contudo, também uma súplica para que se pausassem os alaridos que se seguiam: dos prognósticos sombrios ou celebrantes sobre as mudanças que a pandemia provocaria nas engrenagens corroídas do mundo globalizado às guerras que se travariam nas telas midiáticas entre signos, palavras, imagens. "Infodemia", categorizava a OMS: uma epidemia pelo excesso de informações falsas, propagadas pela web e grupos de WhatsApp, um processo de desrealização social e contágio de afetos ressentidos, suicidas. É preciso silêncio, é urgente escutar os mortos. 
Às imagens das covas rasas como morte anônima de um corpo coletivo (fig. 1), se contrapunham, à época, as imagens das Igrejas católicas vazias que, interditadas por cuidados sanitários de se abrirem aos cultos presenciais, transmitiam suas missas ao vivo pelas redes e televisões. Nos templos vazios, fotografias de seus fiéis, coladas nos espaldares dos bancos, substituíam o corpo ausente (fig.2). De ressonâncias te-

Figura 1

Michael Dantas

Foto aérea de 21 de junho de 2020, do cemitério de Nossa Senhora Aparecida, em Manaus, Amazonas - AFP. Disponível in: https://www.opovo. com.br/coronavirus/2021/01/01/ manaus-registra-recorde-de-internacoes-por-covid-e-abertura-de-covas-na-vespera-de-reveillon.htm ológicas e míticas, a comunidade como corpo coletivo guarda nessas duas imagens - as covas vazias e as fotografias dos fiéis na imagem televisiva da missa - complexos cruzamentos entre a comunidade da morte e a da imagem como corpo coletivo.

Da antiguidade grega ao cristianismo, a experiência do corpo no ocidente foi regida pela dualidade metafísica entre essência e aparência, alma e corpo; pela perda da exata conformidade da criatura à imagem e semelhança do Deus judaico-cristão; pela economia encarnacional do pensamento cristão que, como argumenta Marie-José Mondzain, fundamenta no ocidente a relação com a imagem. Na argumentação iconófila, Cristo, em sua dupla natureza, Verbo e Carne, é o ícone, a imagem natural de uma Invisibilidade, que serviria de modelo à produção das imagens artificiais pelo homem. A face de Cristo converte-se na matriz das visi-

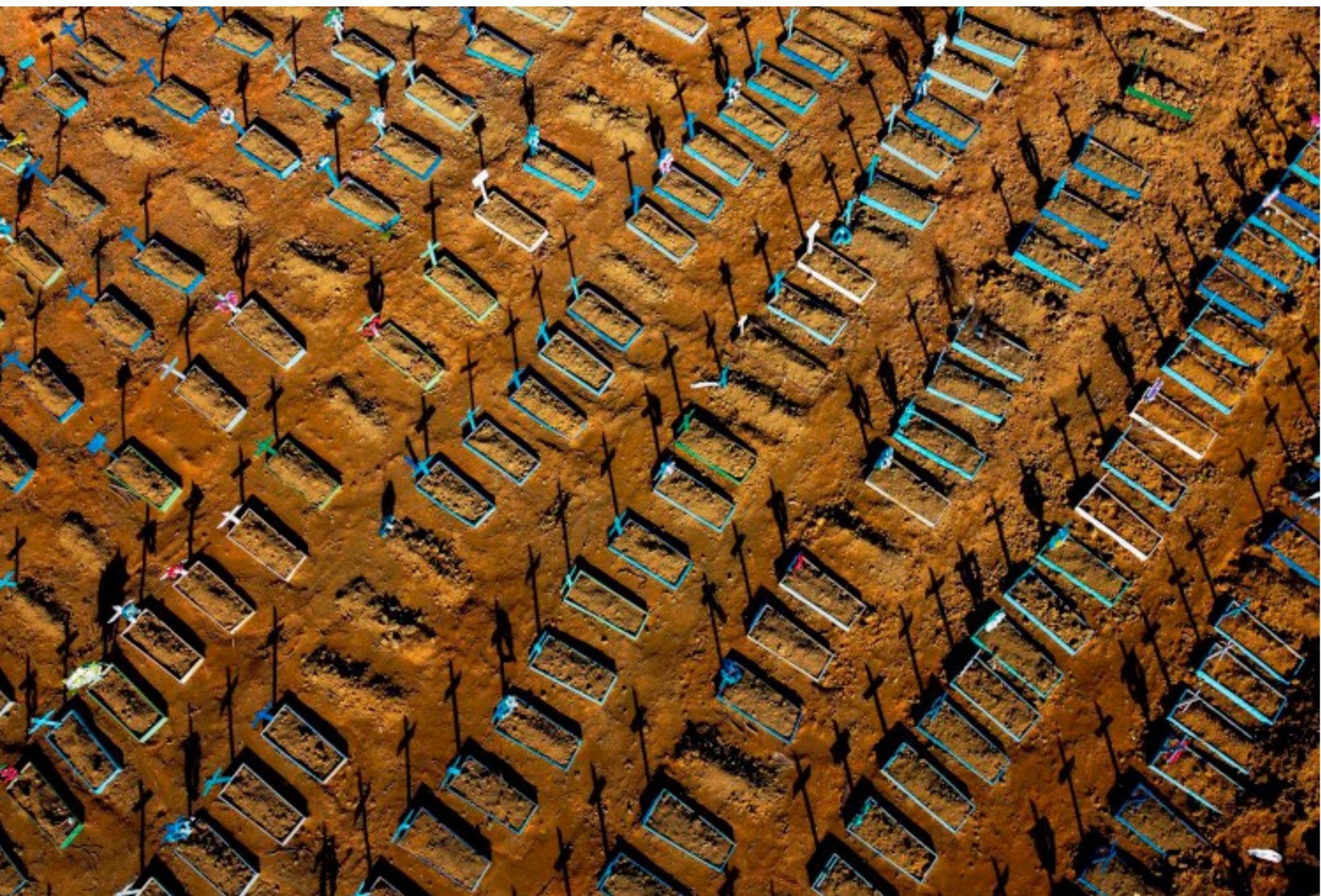


Figura 2

Igreja em Joinville

SC, 2020. PAS-

COM - Disponível in: https://www. diocesejoinville. com.br/informa/ fotos-de-fieis-sao-colocadas-em-igreja-no-bairro-paranaguamirim-em-joinvil le-2020-04-02-17-

19-54

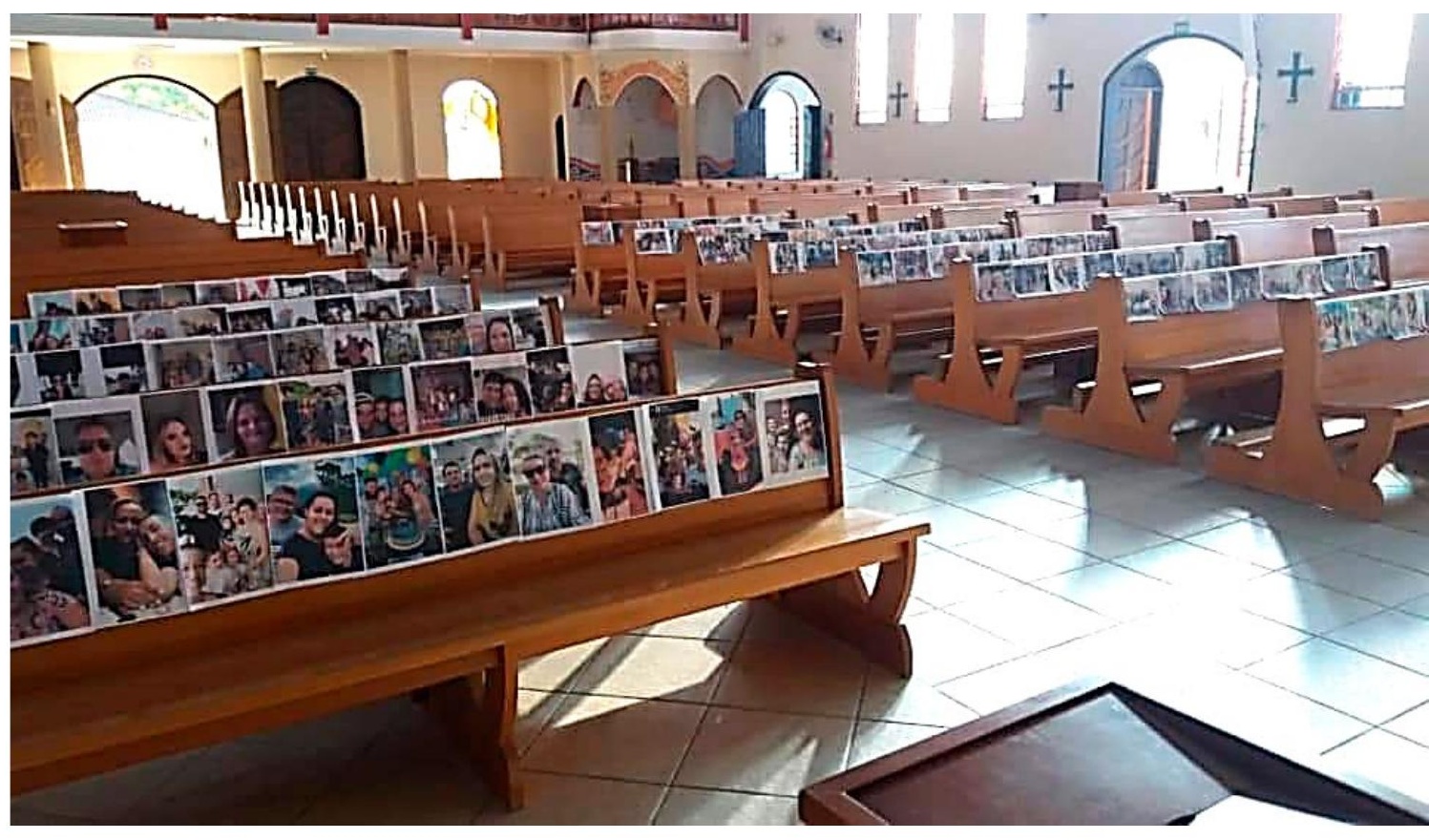

bilidades partilhadas, sua Paixão na paixão da imagem a imitar, reunindo todos os destinos e paixões em uma "única fábula"1 aquela da redenção da própria Humanidade. A imagem é, assim, lugar do pensamento do corpo como traço histórico da civilização cristã, argumenta Jean-Marie Schaeffer. Há uma ambivalência intrínseca ao corpo e sua imagem na arte ocidental: o belo nu e ideal seria tensionado pelo corpo monstruoso, a imagem em semelhança à divindade pelo corpo decaído e obsceno, a carne do Verbo à opacidade sem contornos de sua animalidade. ${ }^{2}$ Corpos que transcendem e conformam a carne, mas que trazem o risco sempre iminente de uma convulsão em seu interior, de uma mútua precipitação. Entretanto, o corpo político, o corpo social, o corpo coletivo são ecos do corpo erguido como metáfora de unidade e comunhão do cristianismo.

Corpus é a tradução latina de sôma (do grego, corpo). Corpus Mysticum encontra-se pela primeira vez nas epístolas de Paulo que deixa o hebreu e o aramaico ao escrevê-las em grego, iniciando um debate teológico que estenderá por séculos entre as acepções de carne e corpo (sarx, sôma), entre presença eucarística e sua simbolização na comunhão, entre o enigma da carne que

1 MONDZAIN, Marie-José. L'helléno-christianisme. In: Le Commerce des Regards. Paris: Éditions du Seuil, 2003. P.87.

2 SCHAEFFER, Jean-Marie. O corpo é imagem. Trad. de Ana Cavalcanti. In Revista Arte\& ensaios 16, 2012-01. Disponível in: https://www.ppgav.eba.ufrj.br/wp-content/uploads/2012/01/ae16_ Jean-Marie_Schaeffer.pdf 
se torna o corpo místico de Cristo no mistério da liturgia comunitária e com o corpo institucional da Igreja. "Se o Verbo se fez Carne na encarnação, a humanidade foi chamada a fazer corpo com Cristo", diz padre Henri Lubac. Mondzain, a partir de Lubac, analisa as transformações semânticas do uso das palavras carne e corpo em hebraico e aramaico, em grego e latim, que legitimaram o Corpo eucarístico e o Institucional. Ou seja, como se operou, nas traduções, a transformação progressiva do Verbo que se fez carne no corpo da Virgem, transfigurado no corpo de Cristo distribuído no sacramento (ofertado em sacrifício para redenção da humanidade), como corpo comunitário eucarístico e o institucional da Igreja. Nos evangelhos dos apóstolos, o Verbo se fez carne e não corpo. Paulo inverteria os sentidos: para a queda da carne no pecado é preciso um só corpo institucional e salvador. Se a carne é ofertada em sacrifício do próprio Deus imolado, que funda a comunidade e a salva, o corpo é construção da Humanidade. A carne redimida se torna corpo sacramental distribuído em eucaristia e que termina por se fazer "Um" com o corpo que se constituirá pela Igreja de Cristo. É esse sentido de universalidade e institucionalidade que a acepção paulina nos legaria: o corpus mysticum teria Cristo como cabeça e, como membros, a comunidade de cristãos, a Igreja e a própria humanidade convertida. O corpo místico rompe com a lei hebraica da separação entre visível e invisível, entre judeus e outras nações, numa nova aliança, um novo contrato de união entre todos os homens que querem partilhar o corpo e o sangue crísticos. Segundo Mondzain, o corpo místico, que tem como cabeça Cristo e como membros a comunidade de cristãos e da própria humanidade, iria influenciar as acepções de corpo que se seguiriam.

Evoquemos as comunidades monocéfalas e fusionais que - do frontispício de Leviatã (1651) de Thomas Hobbes à iconografia política do nazismo e fascismo, em suas propagandas e filmes como O triunfo da vontade (1935) de Leni Riefenstahl - cujas cabeças são seus ditadores deificados e o corpo (coletivo), a comunidade abstrata e idêntica que ele produz (ariana, nacionalista, etc.). Se a cabeça do líder tinha face e voz, o corpo da nação era a massa indistinta de uma comunidade total e narcísica.

São célebres as frases desencantadas de Hobbes: "a guerra de todos contra todos" (bellum omnium contra omnes); "o homem é o lobo do homem" (homo homini lupus). Para Hobbes, o Estado surge de um pacto nascido do medo. Há, em sua análise, uma diferença entre povo - persona una e indivisível que se governa regularmente e que só tem uma única vontade soberana (concepção orgânica do corpo do povo no lugar do corpo do rei) - e multidão - conjunto heterogêneo, desarmônico e desorganizado que não pensa, não fala e ninguém fala em seu nome. À multidão, Hobbes dá a figura 
mitológica da Hidra de Lerna, o monstro de muitas cabeças, representação do mal em sua reprodução desenfreada. Em sua natureza pré-política, prevalece a heteronomia das vontades particulares que não possui outro destino que a "guerra de todos contra todos". Se os animais possuem um pacto natural, os homens precisam de um pacto artificial. Por isso a multidão só pode pretender, na república, a disciplina e a glória da obediência: apenas a autoridade garante a unidade e a paz social. A passagem da multidão ao povo, à substância propriamente política da ordem estatal centralizada, não é natural, mas um artifício necessário para transcender as particularidades discordantes. O advento do povo no discurso político em Hobbes, em Leviatã, ${ }^{3}$ marca o passo do estado da natureza ao estado civil, ou da simples agregação mecânica à associação orgânica fundadora de um corpo novo.

No frontispício do livro Leviatã, na figura desenhada por Abraham Bosse (fig.3), se a cabeça é a condutora das vontades, o corpo é constituído por miríade de homens indiferenciados. "O homem artificial existe graças a eles", diz Carlo Ginzburg. "O Leviatã, através do pacto que os liga, e que eles mesmos construíram, representa o deus mortal, o Estado, com a espada numa das mãos e o báculo na outra. Para Hobbes, o poder do Estado não se apoia somente na força, mas na sujeição, awe: a palavra que vimos aparecer em posição estratégica nos trechos do Leviatã dedicados à origem da religião e do Estado. Hobbes usara a mesma palavra, como verbo (awed), em sua tradução da página de Tucídides sobre os efeitos da peste". ${ }^{4}$

Iconografia similar podemos perceber nas comunidades monocéfalas do nazi-fascismo. "Comunidades" que eliminaram em genocídios épicos o que lhes diferia, na exclusão sistemática do Outro transfigurado em inimigo. Nos filmes de Leni Riefenstahl, como O Triunfo da vontade (fig. 4 e 5), o exército e a massa, que assistem o discurso de Hitler, não possuem individualidade. Estes conformam-se como o grande corpo coletivo da nação ariana, enquanto a cabeça do ditador mitificado, sua face e voz, domina a cena. No extremo oposto, os que agonizavam nos campos de concentração: corpos esquálidos que não eram mais corpos, rostos descarnados e sem reflexo (por isso abundam relatos de como pequenas superfícies espelhadas eram guardadas e partilhadas),

3 HOBBES DE MALMESBURY, Thomas. Leviatã ou matéria, forma e poder de um Estado eclesiástico e civil. Trad. de João Paulo Monteiro e Maria Beatriz Nizza da Silva. São Paulo: Nova Cultural, 1988. [Col. Os Pensadores].

4 GINZBURG, Carlo. Medo, reverência, terror: quatro ensaios de iconografia política. Trad. de Federico Carotti, Joana Angélica d'Avila Melo e Júlio Castañon Guimarães. São Paulo: Companhia das letras, 2014. 
Figura 3

Abraham Bosse desenho do frotispício do livro Leviatã de Thomas Hobbes, 1651

Figuras 4 e 5 Leni Riefestahl O triunfo da vontade, 1935
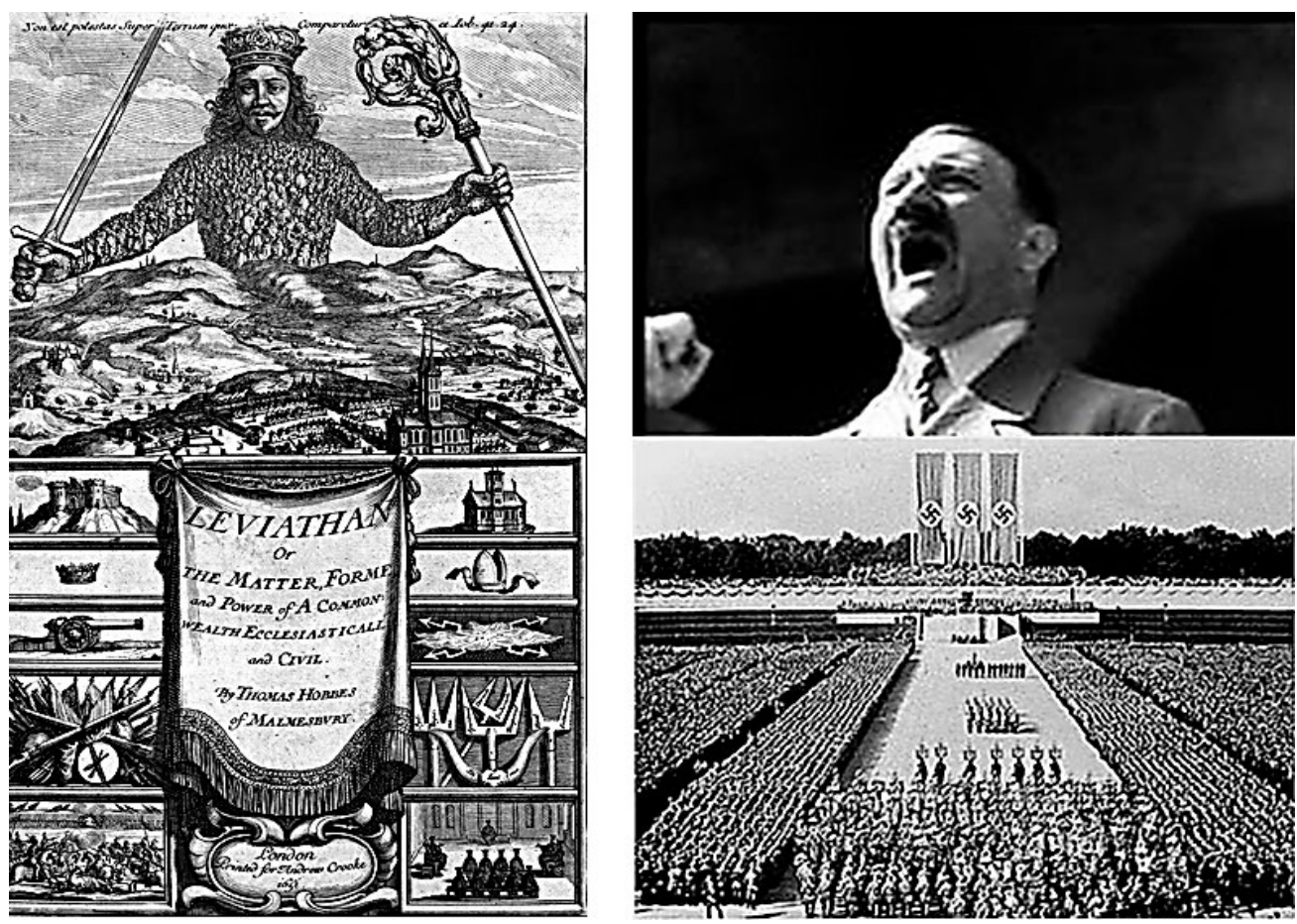

A aparição daqueles que teriam direito a serem incluídos na imagem da humanidade sempre foi submetida a uma seleção ferina. A história é contada (e exibida) pelos vencedores, como na conhecida tese sobre a história de Walter Benjamin. Quem regula, pela inclusão de sua imagem, a entrada na comunidade humana? Que imagem tem a humanidade? Como mostrar então que essa humanidade não é a figura abstrata do Mesmo e do Semelhante? Que essa humanidade tem diferentes rostos e vozes, gestos e desejos singulares, inadequações e cizânias? Como devolver o direito à aparição (à imagem) daqueles condenados à inexistência estética e política? Como dar visibilidade aos sem-imagem e sem-palavra, incluí-los na imagem da humanidade? Que corpos dissemelhantes foram regurgitados para fora da comunidade humana e de sua imagem?

Tem-se na sociedade nazista uma coisa extraordinária: é uma sociedade que generalizou absolutamente o biopoder, mas que generalizou, ao mesmo tempo, o direito soberano de matar. (...) o Estado nazista tornou absolutamente coextensivos o campo de uma vida que ele organiza, protege, garante, cultiva biologicamente, e, ao mesmo tempo, o direito do soberano de matar quem quer que seja - não só os outros, mas seus próprios. (...) Temos um Estado absolutamente racista, um Estado absolutamente assassino e um Estado absolutamente suicida5 (FOUCAULT, 2010).

5 FOUCAULT, Michel. Em defesa da sociedade: curso no Collège de France (1975-1976). Trad. de Maria Ermantina Galvão. São Paulo: Martins Fontes, 2010. P. 219. 
O poder se realiza pela administração da vida, concluiu Michel Foucault, ao analisar as transformações de sua natureza e funcionamento na sociedade moderna. Um "biopoder" que se materializa no adestramento e na instrumentalização dos corpos, confinando e excluindo aqueles que diferem ou se desviam dos comportamentos normatizados, como o louco, o pária, o infame. Mas, o extremo dessa exclusão é a redução da vida dos indesejáveis à sua condição biológica, à negação de seu estatuto político e de sua própria humanidade. Reificados, reduzidos à coisa, jogados em zonas de anomia, podem ser mortos impune e violentamente. Se no regime de soberania, que vigorou até o século 18, o soberano possuía o direito de fazer morrer se fosse ameaçado, a partir de então, instala-se o que o filósofo definiu como "biopoder", a administração das condições de vida da população. Ao "fazer morrer e deixar viver" da soberania, o "fazer viver e deixar morrer" da biopolítica.

É a partir da biopolítica de Foucault, em relação com a ideia de estado de exceção (via Carl Schmitt e Giorgio Agamben), que Achille Mbembe conceitua o que batizou de "necropolítica". Ainda que Foucault afirme que na constituição do biopoder está o racismo, sua referência não lhe dá centralidade devida. Mbembe interroga então se o paradigma biopolítico da modernidade não seria a plantation, ao invés do campo de extermínio. A escravidão, dirá, foi a primeira manifestação e laboratório de biopoder, e que resultou em "uma tripla perda: do lar, de seu estatuto político, do direito sobre seu corpo. Essa tripla perda equivale a uma dominação absoluta, uma alienação de nascença e uma morte social (expulsão da humanidade)". ${ }^{6}$ O humanismo ocidental é, portanto, indissociável do racismo, pois inventou o negro como um corpo-mercadoria, corpo-moeda, corpo-objeto desde o século 16. E mesmo depois, sob o projeto moderno da emancipação de uma humanidade igualitária - a universalidade concebida no ideário iluminista -, ele manteve-o nas sombras, sob a morte concreta e simbólica que ainda hoje determina quem deve viver e quem deve morrer nas periferias planetárias.

E é da periferia planetária que assistimos, entre atordoados e impassíveis, os assassinatos cotidianos em nossas favelas de negros e pobres, o genocídio indígena que se perpetua por séculos, a trágica estatística de sermos o país que mais mata LGBTQI+, o feminicído alarmante, o fundamentalismo que persegue e demoniza a religião que não é a sua, o gozo com o linchamento nas ruas e redes de todo o país. Em nossa versão da banalidade do 
mal, destruir os indesejáveis é antes destituí-lo de sua condição humana, e nada exemplifica melhor do que os mortos (esses matáveis) nas favelas, campos e florestas destes país.

Uma "distinção ontológica", como fala Vladimir Safatle, entre pessoas (com direitos e proteção do Estado) por quem se lamentam as mortes, e coisas (ao desamparo do Estado e excluídos da humanidade) cujas mortes Ihes são indiferentes.

Em Para além da necropolítica, ${ }^{7}$ Safatle lança a hipótese de que a pandemia veio transformar a gestão biopolítica global em um novo modelo que teria o Brasil, e sua matriz colonial, como o laboratório de sua instauração. Um modelo imanente ao neoliberalismo autoritário "e sua incapacidade de preservar macroestruturas de proteção social e redistribuição em um cenário de acirramento de desigualdades e concentração." Experimentamos, aqui, um deslocamento do modelo necropolítico de Mbembe (como gestão de morte e sujeição social de determinados grupos) para o paradigma suicidário, que estenderia sem reservas a gestão do medo, do ressentimento e da morte a todos os setores da população sob sua jurisdição. $\mathrm{O}$ Estado abdica assim de sua função protetora do "fazer viver", para apenas "deixar morrer". Insensível à morte, o Estado se torna ator contínuo de sua própria catástrofe, numa expansão destrutiva de todas as camadas sociais, ainda que, sobre os mais vulneráveis, a tragédia se concretize de modo mais rápido e avassalador.

O termo "Estado suicidário" é extraído do texto L'insecurité du territoire em que Paul Virilio analisa a dinâmica da violência do fascismo expressa no telegrama 71 de Hitler: "Se a guerra está perdida, que pereça a nação". Ao sentir-se encurralado, Hitler bradou a todos a consumar a destruição integral, dos recursos do país à de seu próprio povo." A lógica do estado predador se generaliza para a integralidade do corpo social, como o ator contínuo de sua própria catástrofe, o cultivador de sua própria explosão, o organizador de um empuxo da sociedade para fora de sua própria auto-reprodução". ${ }^{9}$

7 SAFATLE, Vladimir. Para além da necropolítica. Disponível in: https://www.n-1edicoes.org/textos/191.

8 VIRILIO, Paul. L'insécurité du territoire. Paris: Galilée, 1976.

9 SAFATLE, Vladimir. Para além da necropolítica. Op.cit. 
Para Gilles Deleuze e Félix Guattari, o fascismo não coincide perfeitamente com o totalitarismo, este diz respeito ao Estado e suas máquinas abstratas de sobrecodificação, mesmo o exército é na ditadura militar sua máquina abstrata. O fascismo é a máquina de guerra que se apropria de um Estado "suicidário", como o definiu Paul Virilio, "um niilismo realizado". Por isso, dizem os filósofos, os nazistas anunciavam, ao mesmo tempo, "núpcias e morte, inclusive a sua própria morte e a dos alemães". (...) "Eles gritavam 'mata' e 'bravo' pela morte do outro, (...) porque queriam esta morte que passava pela dos outros (...). Uma máquina de guerra que não tinha mais objeto a não ser a guerra, e que aceitava abolir seus próprios correligionários antes do que deter a destruição". ${ }^{10}$

É essa pulsão destrutiva e suicida que assombra outra vez nossos corpos, nossas condutas cotidianas, nossas formas de vida; ela não é exterior, é o que nos faz desejar o que nos domina e nos mata. É "metastática", como diria Deleuze e Guattari, mas uma metástase que se dissemina infiltrando-se no que somos: dos pequenos ódios à intolerância religiosa ou política, da ausência de empatia aos gritos histéricos de apoiadores bolsonaristas diante de hospitais covidários. Se os governos ditatoriais foram a potencialização e a culminação dessa subjetividade, creio que eles se instalam ali onde impera, não o vazio nem o desamparo, mas justamente a angústia de não conseguir encará-los.

A cabeça do líder (como ocorreu no século 20, com Hitler, Mussolini, Franco, Salazar, as ditaduras da América Latina, etc.) foi a culminação e a personificação do ódio à alteridade, que reflui de volta, como o retorno do recalcado. Na outra face do espelho da comunidade narcísica, ressurgem as cabeças espectrais, como poder de conjugação fusional, na figura do inimigo a ser decapitado.

Safatle supõe que a noção de estado suicidário retorna atualmente em laboratórios mundiais do neoliberalismo autoritário, "como o funcionamento normal de uma situação em crise perpétua. Pois trata-se de defender a tese de que catástrofes humanitárias, como essa produzida pelo governo brasileiro diante da pandemia (...), funcionam como parte de uma política de pressão em direção a modificações paradigmáticas no exercício do poder." Trazendo ao debate autores que vão de Adorno a Lacan, Safatle

10 DELEUZE, Gilles; GUATTARI, Félix. Micropolítica e segmentaridade (Tradução de Suely Rolnik). In: Mil Platôs volume 3 - capitalismo e esquizofrenia, vol. 3 /v.3.Tradução de Aurélio Guer ra Neto et alii. Rio de Jan eiro: Ed. 34, 1996 (Coleção TRANS), Pp. 83-115. 
analisa o discurso de liberdade e do individualismo sob a égide neoliberal aplicada a um país de herança colonial (a liberdade compreendida como propriedade sem responsabilidade com o outro), o (auto) sacrifício e a pulsão destrutiva, a consolidação da indiferença e da desafecção como afeto social fundamental, o processo de implosão suicidária do corpo social.

Como a arte responde a estes tempos de catástrofe, de estilhaçamento dos laços socais, de morte do corpo coletivo?

\section{Quase-oração}

Ao longo de dias, um grupo de artistas se revezam ao vivo em duplas numa rede social (Instagram), na contagem sem interrupção dos números de mortes pela covid-19. Idealizada pelo artista Diego Groisman, a ação é performada por quase uma centena de voluntários que aderem à comunidade de prece. Diego Groisman e Patrícia Rangel, em lados opostos do Atlântico, enunciaram o número 1 . O cansaço na fala ininterrupta, a garganta seca, a atenção exigida na enumeração, a respiração que falha extenuada, confundem-se com a exaustão destes tempos de asfixias, de dor da perda de parentes e amigos, da dor pela indiferença, da dor pela ausência de dor. Os números enunciados têm a sonoridade mântrica das orações. Sua (quase) repetição compassada retira a morte e sua tragédia da chave da indiferenciação quantitativa, revertendo-a nela mesmo. Converte torpor em lamento, número em luto. Nas telas, os rostos dos sobreviventes se olham especularmente; velam os sem rosto, sem voz, sem corpo da opacidade das estatísticas.

\section{Réquiem NN}

Na grande noite das Américas, naturalizamos as valas comuns, os cadáveres sem nome, os mortos anônimos de nossa histórica violência. As guerras contra os civis, as guerras contra os povos, as guerras contra saberes e crenças, as guerras contra o corpo da terra. Os rios, os mares, os cemitérios clandestinos, Perus e Condor, denegaram a milhões os ritos fúnebres e sua condição de humanidade.

$\mathrm{Na}$ Colômbia, no final da década de 1970, quando os paramilitares entraram em guerra contra os grupos guerrilheiros, a cidade de Puerto Berrío, situada na curva do rio Magdalena, estava no centro do conflito. Os assassinados, reduzidos a coisa, eram jogados no rio em pedaços. Em geral, o destino desses corpos não identificados, chamados NN ("sem nome", do latim nomen nescio), é a vala comum. Por três décadas, todavia, os aldeões 
de Puerto Berrío recolheram das águas os corpos despedaçados, adotaram suas almas, batizaram-lhes com nomes (muitas vezes seu nome de família). Choraram sua perda, a cruel brutalidade dos dias e das noites. Enterrados no cemitério à margem do rio, decoram seus túmulos, dão-lhes cores, levam-Ihes flores, endereçam-Ihe preces. Creem que assim, dignificados em sua humanidade, acolhidos como um deles, estes protejam e concedam graças aos vivos que os adotaram.

Desde 2006, o artista colombiano Juan Manuel Echavarría realiza o projeto Réquiem NN (fig. 6 e 7): fotografou os túmulos, documentando suas fachadas em constante mudança, e realizou um filme em que os habitantes de Puerto Berrío narram suas histórias, elaborando os traumas de uma "sociedade dilacerada pela violência".11 "Todos os anos durante o mês de novembro, quando a Igreja Católica comemora as Almas dos Mortos, as portas do cemitério se abrem à meia-noite e um homem de capa preta - o Animero, ou Guardião da Alma - convida os fiéis a seguirem em procissão, carregando velas em oração pelas almas dos que partiram para obter o descanso eterno - conhecido na liturgia latina como Requiem Aeternam. (...) Através deste ritual coletivo, a população de Puerto Berrío diz aos perpetradores da violência: "Em nossa comunidade não permitimos que suas vítimas desapareçam; podemos não saber quem eles eram, mas eles se tornarão parte de nós'”. ${ }^{2}$

As muitas conformações das fotos, em diferentes instalações, não atestam um simples arquivo, mas os retratos das faces-fachadas em permanente e viva metamorfose, a memória da violência traumática, o testemunho de suas existências. Na tensão entre a presença do ausente e a estranha materialidade do corpo despedaçado, a obra atualiza o ritual coletivo dos aldeões que as retira da sombra e do apagamento e as insere no pertencimento de um nós indecifrável e, todavia, necessário: dá-lhes imagem e nome, substitui o corpo perdido do morto pelo corpo visual da imagem, prolonga sua presença ausente em um "nós" como interrogação e incógnita, como partilha e pertença.

\section{Pausa para mil compassos}

No carnaval de 2021, os tambores foram silenciados. A aglomeração dos corpos em festa e transe foi sustada pelo distanciamento sanitário; as máscaras em que experimentos a alteridade substituídas pelas máscaras de EPI.

11 A filmagem de Réquiem NN foi realizada em cinco visitas a Puerto Berrío, o filme demorou dois anos para ser concluído. O filme está disponível em: http://www.requiemnnfilm.com/view.html

12 Réquiem NN. Disponível em www.jmechavarria.com. 
Figura 6

Juan Manuel Echavarría Réquiem NN, 2006 Mausoléu de Puerto Berrío



Figura 7

Juan Manuel Echavarría Réquiem NN, 2006 (detalhe)

Entre o carnaval e domingo de Páscoa, Felippe Moraes instalou na janela de seu apartamento no Mirante do Vale, o edifício mais alto da cidade de São Paulo, letreiros em neon com versos de canções brasileiras. No lugar do silêncio dos tambores, quatro frases da série Samba exaltação, reluzem na cidade no momento da ameaça: Agoniza mas não morre, de Nelson Sargento; Uma pausa de mil compassos, da canção Para ver as meninas de Paulinho da Viola; E viver será só festejar por Evandro Rodrigues, Baianidade Nagô; Quero viver no carnaval, em que Moraes altera a letra dos compositores Luiz Antônio e Eurico Campos de Quero morrer no carnaval. Os letreiros têm a aparência de efígies publicitárias, cuja estratégia é fazer crer que se deseja o que se vê. Na gestão comercial do visível, figuras de felicidade e infelicidade são vendidas como produtos a serem consumidos na hipnose capitalista. Nosso desejo, nossa capacidade de imaginar outros mundos e outros possíveis nos são sequestrados. É preciso então enganar seu dispositivo, transformá-lo em seu re-verso.

No ensaio "A gramática dos tambores", ${ }^{13}$ Luiz Antonio Simas e Luiz Rufino falam do papel do tambor na cultura da diáspora africana, em que cada toque conta uma história, em que cada orixá, vodum ou inquice tem seu toque próprio. Toques para expressar conquistas, alegrias, tristezas, cansaço, realeza, harmonia, suavidade, sensualidade, guerras... Nas festas do candomblé - pela incorporação e pelas danças, trajes e emblemas -, são relatadas as passagens de suas trajetórias míticas, ritualiza-se o mito em música, coreografia, crença e arte, para que a comunidade dele se recorde, e extraia algum saber exemplar como modelos e comportamentos a seguir ou a evitar.

Silenciados aqui pela escravidão, foram os tambores que contaram histórias. Seus iniciados aprendiam a reconhecê-las e recontá-las. Dizem: "se a chibata é grito de morte, o tambor é discurso de vida. Eles, os tambores rituais, possuem gramáticas próprias: contam histórias, conversam com as

mulheres, homens e crianças, modelam condutas e ampliam os horizontes do mundo. Foram eles que muitas vezes expressaram o que a palavra não podia dizer e contaram as histórias que os livros não poderiam contar e as línguas não poderiam exprimir." ${ }^{14}$

13 SIMAS, Luiz Antonio; RUFINO, Luiz. A gramática dos tambores. In: Fogo no mato: a ciência encantada das macumbas. RJ: Mórula Editorial, 2019. Pp. 57-64.

14 Idem ibidem. 
Algo similar ao que diz Mbembe sobre a plantation: "Sombra personificada", transformado em mera ferramenta, o escravo foi, entretanto, capaz de romper com o puro mundo das coisas, do qual era um fragmento, e de extrair de qualquer objeto, linguagem ou gesto, sonoridades e danças. De mostrar, enfim, "uma capacidade polimorfa" de sobreviver e de transformar as relações por meio da música e de seu corpo, que todavia era propriedade de um outro.

É o que acontece também nas escolas de samba, em suas conexões genéticas com os terreiros. Mesmo quando o enredo falava de "pátria" ou se referia a histórias oficiais (principalmente durante as ditaturas), o toque da bateria contava e celebrava outras histórias, aquelas das diásporas, "perceptíveis para aqueles que conhecem a gramática dos tambores".

Ainda que as vozes sejam silenciadas, ainda que os corpos e seres sejam reduzidos a coisas, ainda que as chibatas e as fábricas imponham o mesmo e opressivo ritmo, os tambores falam pelas mãos que os tocam, os corpos reagem em coreografias de vida, os tempos cósmicos e os ancestrais comparecem e atualizam saberes e memórias abafados. E seguem falando... A batida tradicional de funk carioca tem como base o toque do alujá de Xangô, diz Simas. Mesmo que não saibam, mesmo em tempos de fundamentalismos e perseguição religiosa, quando tocam e dançam o funk, é a prece por justiça que ecoa ao fundo.

O poema é impossível depois de Auschwitz, disseram. Mas é então que ele se fez necessário, refutaram. A poesia não tem exatamente sentido, disse Jean-Luc Nancy, mas ela é o acesso à possibilidade do sentido, ainda que sempre protelado - é sua "demanda exorbitante". ${ }^{15}$ Uma pausa de mil compassos é um apelo para que não mais exista a imposição de um ritmo sobre outro, é abertura aos ritmos diferenciados das existências. É um verso, um reenvio como em seu étimo. Antes de ser refém da página, o poema foi canto e rito. Sedução pelo abismo das palavras, de onde elas surgem e se desviam em eterno recomeço. Interseção e choque entre os sinais sonoros e gráficos e seu sentido semântico. O poema extrai a palavra da cristalização dos costumes, e, da língua, sua potência de nomear mundos. Voragem que escava pausas para que todos possam falar, para que cada um possa dançar em seu próprio compasso... O verso é uma virada, um reverso de sentido. Um giro que desafia e incorpora os deuses da palavra. O poema é uma gira. 


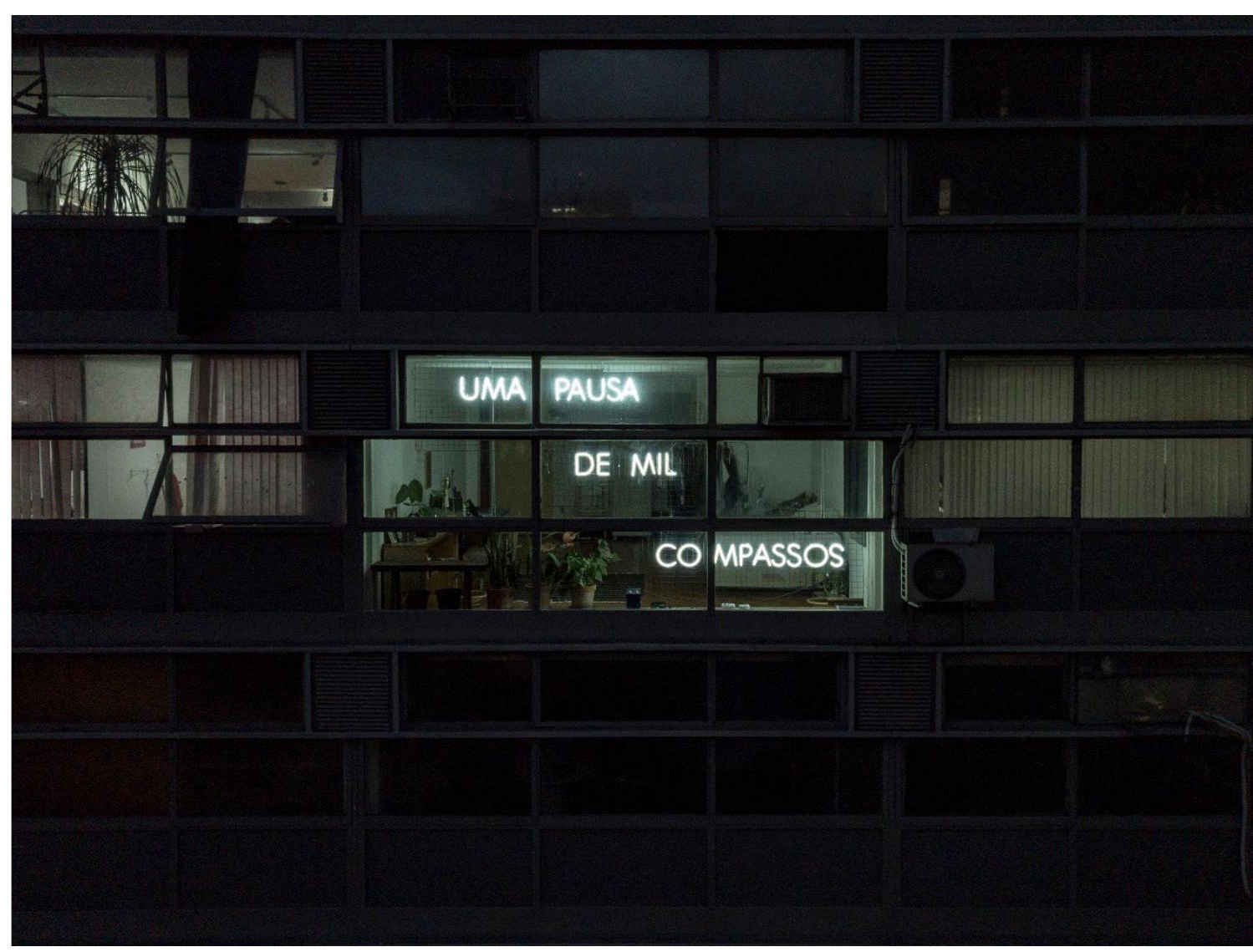

Figura 8

Felippe Moraes Samba exaltação/ Uma pausa de mil compassos, 2021 Letreiro em neon Foto: Gianluca Misitti

\section{As máscaras e as outras formas do humano}

"A morte foi primeiramente uma imagem, e sempre persistirá como tal, pois não sabemos o que a morte realmente é." A frase de Gaston Bachelard é citada por Régis Debray. A própria imagem é "terror domesticado", ${ }^{16} \mathrm{diz}$ o teórico, ao associá-la à morte, às máscaras funerárias em que o rosto humano da pessoa amada desaparece na terra para se perpetuar nas máscaras funerárias. Desde as culturas pré-históricas, as máscaras já estavam cobrindo o rosto perdido ou invocada no culto dos mortos. Plínio, o Velho, definiria a imago, a noção romana de imagem, a partir dos retratos obtidos com as máscaras mortuárias. Imaginum Pictura era a efígie obtida com as máscaras mortuárias expostas nas casas dos nobres romanos, como genealogia familiar e transmissão às gerações futuras, do passado honroso de seus membros. Técnica de contato direto por impressão, obtinha-se um molde

16 Apud BELTING, Hans. Por uma antropologia da imagem. In: Concinnitas. Revista do Instituto de Artes da UERJ, v.2, n.8, 2005. Disponível in: https://www.e-publicacoes.uerj.br/index.php/ concinnitas/article/view/55319 
negativo de gesso no rosto do morto, e suas retiradas positivas em cera. Uma imagem-matriz de extrema semelhança (o rosto do morto), como aponta Georges Didi-Huberman, destinada a tornar legítima a posição da pessoa na instituição da gens romana, confirmar sua dignidade pública. Se o início da história da arte implica uma morte na origem, Plínio introduziu seu ponto de vista genealógico "mediante o testemunho da morte". ${ }^{17}$

Se o corpo perdido do morto é substituído pelo corpo visual da imagem, prolongando sua presença ausente no seio da comunidade, a imagem então se constitui no encontro entre os "meios" e o "corpo perdido", concluirá Hans Belting. "Meio-imagem-corpo"18 é o mecanismo central de sua antropologia da imagem: as imagens acontecem entre nós, que as olhamos, e os meios com os quais respondem ao nosso olhar. A máscara fúnebre, o retrato, o meio fotográfico ou mesmo as telas dos dispositivos digitais são, portanto, instâncias em que ocorre a presença do ausente e se reitera a estranha materialidade do corpo perdido.

A questão do retrato começa talvez no dia em que, diante de nosso olhar aterrado, um rosto amado, um rosto próximo cai contra o solo para não mais se levantar. Para finalmente desaparecer na terra e se misturar a ela. A questão do retrato começa talvez no dia em que um rosto começa diante de mim a não estar mais aí porque a terra começa a devorá-lo. (...) O que os retratos fariam seria apenas poetizar, produzir uma tensão sem recurso e a difícil gestão de sua perda. (..) A questão do retrato seria uma questão de lugar. Ou uma mágica resposta do lugar ao rosto ausente. ${ }^{19}$

No distanciamento, nos cuidados sanitários de não nos tocarmos, as telas virtuais tornaram-se o único meio de vermos o rosto do outro. Em presença, é sempre a máscara. Somos obrigados a usá-las para preservar nosso corpo, e o do outro, vivos na comunidade. A tela, o rosto, a máscara interagem reinventando a partilha do tato e do contato, a (co)presença virtual e física, as relações de distância e proximidade dos corpos e seus códigos de comunicação, de apelo e repulsa, na vida cotidiana. Não seria espantoso, portanto, que as máscaras que invadiram a paisagem, a face e a pele de nossas vidas, se tornasse uma superfície de indagações e enigmas para os artistas. São as máscaras que invadem as redes sociais, em objetos, retratos, ações.

17 Didi-Huberman, Georges. Imagem-matriz. In: Diante do tempo: história da arte e anacronismo das imagens. Trad. de Vera Casa Nova, Márcia Arbex. Belo Horizonte: Editora UFMG, 2015. Pp. 71-100.

18 BELTING, Hans. Por uma antropologia da imagem, Op. Cit.

19 DIDI-HUBERMAN, Georges. O rosto e a terra/ onde começa o retrato, onde se ausenta o rosto. In: Porto Arte, Porto Alegre, v.9, p.61-82, 1998. Disponível em: https://seer.ufrgs.br/PortoArte/ article/view/27751 
O outro advém como um rosto que nos interpela, como um enlace contratual com quem estabelecemos um vínculo social; é o rosto que nos designa à relação, que dá acesso ou barra mundos. Mas é sempre uma incompletude constitutiva. Em várias culturas do mundo, ou para pensadores que sobre ele se debruçaram, como Emmanuel Lévinas e Davi Le Breton, o rosto se abre a abre uma infinidade de concepções de fundo ético e político, mítico ou religioso, íntimo ou coletivo. Se é uma reserva infinita, imediatamente ética e relacional para Lévinas; é a primeira imagem para Belting. Ícone do corpo, o rosto é o ponto de fuga para o qual convergem todas as imagens. "Superfície mais apaixonante da Terra", para Belting, de interditos e revelações, o rosto teve, desde sempre, a história de sua representação entrelaçada à figura fixa da máscara (funerária, de culto ou de teatro). Eis a busca incessante: surpreender seu segredo, desvendar seu encantamento.

Se a máscara funerária media a relação com a morte, como proteção ou memória; é por ela que, no teatro, o ator investe de vida o personagem em sua dramaturgia expressiva. Foi assim que os romanos designaram-na como persona, pessoa; vem de per-sonare, o que faz ressoar a voz. A máscara dos rituais empresta, ao portador, o rosto de outro que se apropria de seu corpo, na "excarnação" 20 de sua face, como diz Belting. Usar a máscara é convocar os mortos, os antepassados, os deuses. Emprestar-lhes a vida que falta, transmutar-se na alteridade, apreender um saber ou mistério. Usar a máscara no ritual é deixar de ser o que é para encarnar o poder do além que se apodera de nós e do qual imitamos a voz, o gesto, o olhar. Êxtase e delírio ao ser possuído pelo outro, fundir-se a ele no transe místico para, ao mesmo tempo, apropriar-se de seu saber original e estranhar-se, destituir-se de si, metamorfosear-se: participar assim da dança dos fenômenos, do ter-se e perder-se incessante, da pluralidade do devir cósmico engendrando seus outros.

Ecoar a voz dos silenciados, devolver o rosto perdido na morte anônima das estatísticas, desvelar as faces de outras humanidades, ouvir os antepassados e os saberes ancestrais. É preciso abrir-se à escuta de um nós além do humanismo ocidental? Fazer da máscara de EPI a superfície de transmutação, metamorfose e potência política? - eis as indagações que podemos depreender das "máscaras" dos artistas.

Todos nós Contraforte (fig. 9) é uma obra em processo Telma Gadelha. Médica de formação, a artista vem produzindo uma série de pinturas de pequeno 


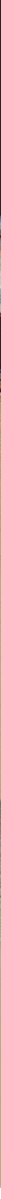

Figura 10

Telma Gadelha Todos nós, contraforte, 202. Vídeo disponível em https://youtu.be/$-9 \mathrm{klthY} 2 \mathrm{PxU}$ gumas dessas pinturas, como se, do umbral entre o reino dos mortos e o mundo dos vivos, o barco de Caronte transitasse entra a dor e a redenção.

Roberta Paiva confecciona máscaras com pequeninos bonecos de plástico adquiridos em suas peregrinações na SAARA, mercado popular do Rio de Janeiro. Estes se assemelham a corpos empilhados que jazem e cobrem parte de seu rosto, como se calassem sua voz, impedissem sua respiração, engolissem sua face. Recordam ainda o corpo do Leviatã, a imagem do povo desenhado na capa do livro de Hobbes; um corpo único formado por miríade de corpos indistintos e despersonalizados, pois subsumidos pelo medo e a obediência. Em Asfixia (fig.11), lúdico e lúgubre, artifício e natureza confundem-se.

O sacrifício é um dispositivo de passagem entre o sagrado e o profano. O sacrifício do Deus cristão abre e funda a comunidade do homem ocidental. O (auto)sacrifício, da máquina suicidária do capitalismo neoliberal, implode o corpo social, como fala Safatle. Funda a comunidade da morte? Interrogaríamos. Máscara e luvas cirúrgicas são feitas com as vísceras de um cordeiro, com seu intestino. Da série Memória Cinestésica (figs. 12 e 13) de Beanka Mariz, que sabe, um dia, elas cobriram a pele de quem as vestiu em sua honra e celebração. Se o imolado permite a passagem entre mundos, o sagrado e o profano, o alto e o baixo, não há porque apartá-lo de sua parte lobo. Homem, lobo e cordeiro são cambiáveis, uma posição 
vicária de enunciação e perspectiva. Se o morticínio não reconhece o outro e o reifica, é preciso trocar de pele, reconhecer que todos têm alma e consciência, abrir-se à comunidade de todos os seres.

"Somos mesmo uma humanidade?", pergunta-nos Airton Krenak. Ou somos "uma pluralidade de formas de vida" interdependentes que trama o

Figura 11

Roberta Paiva

Asfixia, 2020

Máscara de boneca de plástico

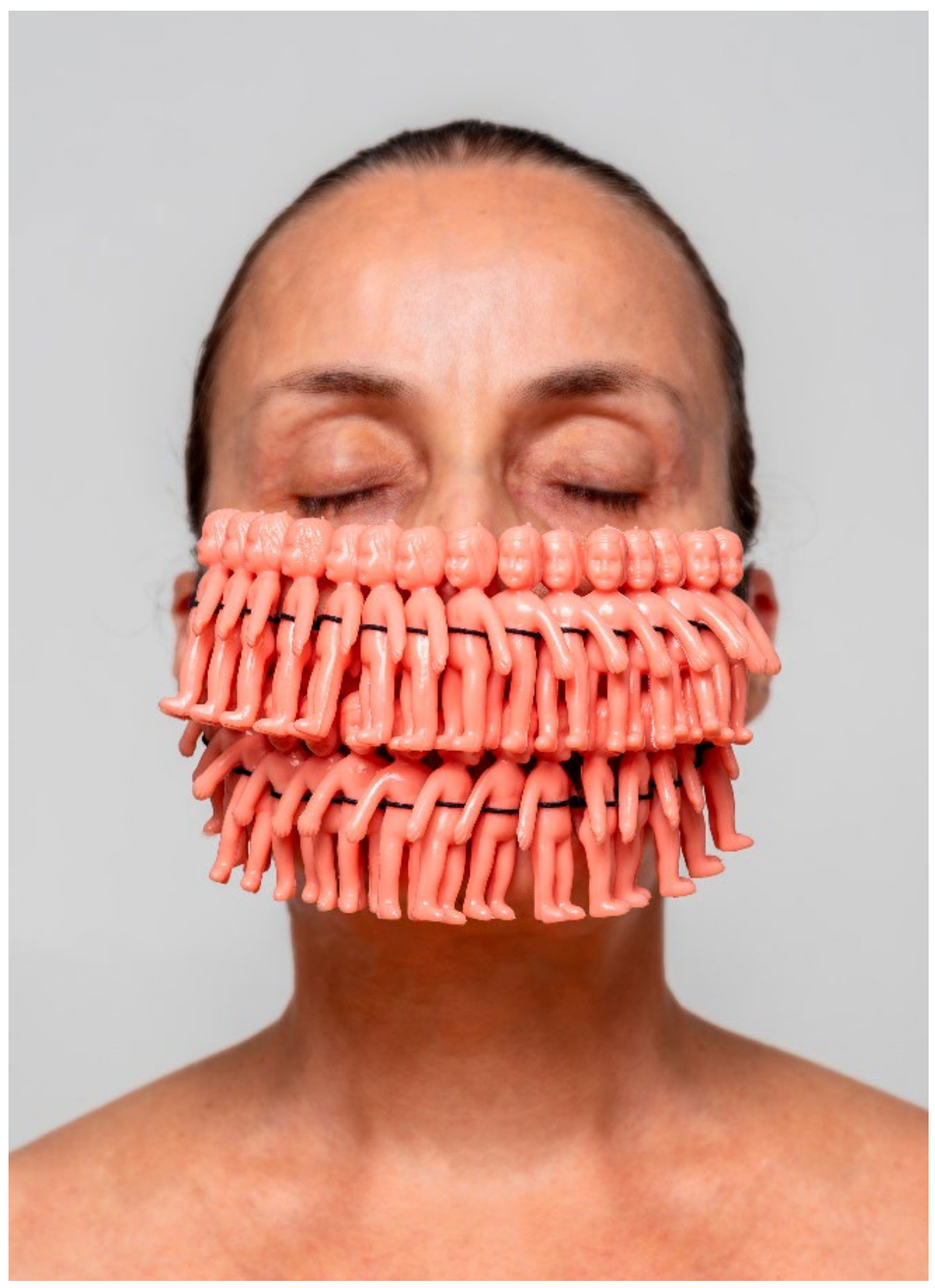


Figura 12 e 13 Beanka Mariz Série Memória Cinestésica /Máscara Cirúrgica e Luvas, 2020. Intestino de cordeiro, fio cirúrgico.
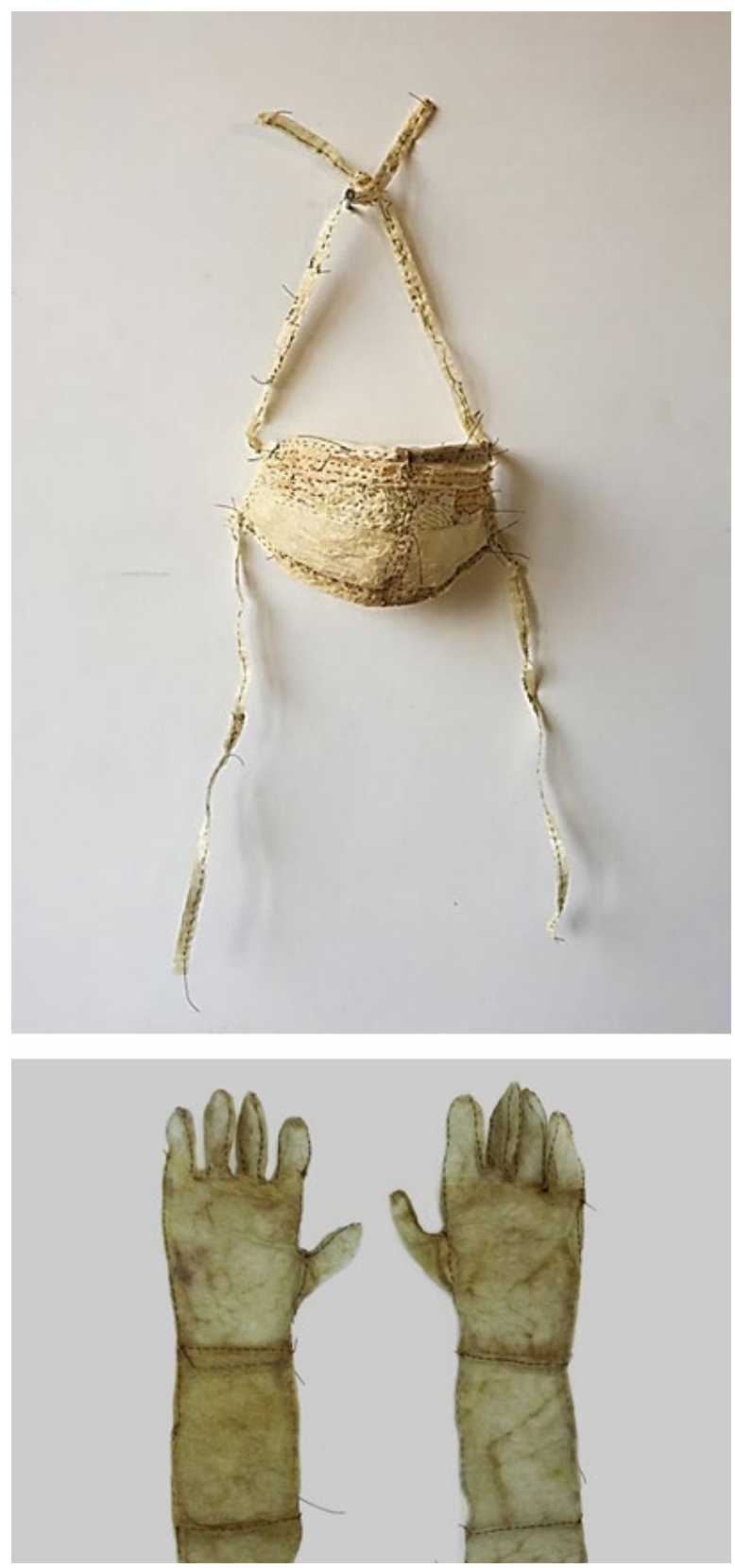

humano e o não humano em um inextricável 'co-tornar-se'? "A ideia de nós humanos nos descolarmos da terra, vivendo uma abstração civilizatória, é absurda", responde. "Ela suprime a diversidade, nega a pluralidade das formas de vida, da existência e de hábitos". ${ }^{22}$

A pandemia agudizou o sentimento de fim de mundo que nos desassossegava há tempos. Ela surge nas franjas das cidades que invadem florestas, na 
fricção interespécies, na extinção da biosfera. Damos corpo a um vírus invisível, vindo de morcegos ou pangolins. Somos seus hospedeiros. Um estranho que se apossa de nós, de nossas vidas e a transforma. Um agente de mutação (biológica, cultural e linguística), capaz de modificar nossa relação com o mundo, com a morte individual e coletiva, com os vínculos e (des) limites entre humano e não-humano? Enquanto contabilizamos os mortos nos jornais televisivos, o pantanal, o cerrado, as florestas, ardem em chamas. Quem é esse nós que morre no mundo? De que mundo falamos? E quem fala quando falamos nós?

Antropoceno, Capitoloceno, Gaia... entre o fim do mundo (como juízo final) e a finitude do mundo, o esgotamento de suas reservas. Pêndulo sobre dois imaginários: a criação e a destruição provocada pelo homem. $\mathrm{O}$ antropocentrismo desse homem arrogante, que submeteu mundo e seres a sua medida, reflexo e domínio predatório, será finalmente abalado? A interdependência planetária das espécies nos coloca sob impasses. Seremos capazes de redescobrir nossa pertença à Terra e nosso indissociável vínculo à totalidade dos seres? Extrema e urgente questão.

Watu é como os Krenak chamam seu avô, o Rio Doce. Em alguns países, Montanhas, Rios, Pachamama, Madre Tierra, se tornaram personalidades jurídicas, cujos interesses são defendidos por representantes escolhidos entre a comunidade. Estaremos à altura de tal revolução, capazes de formular uma política do Cosmos como casa comum?

Por isso os saberes ameríndios, com suas ontologias relacionais e perspectivistas, são tão buscados neste momento. Por isso abordagens cosmo-ecológicas, estudos multiespécies, humanimalismo, metafísicas indígenas, epistemologias africanas, saberes quilombolas são convocados a decolonizar o pensamento, a dar atenção às muitas formas de vidas, nas quais estamos entrelaçados, dos fungos às estrelas, em nosso co-constituir-se.

Ailton Krenak nos convoca a vivermos a comunidade de todos os seres, além das abstrações ocidentais, como uma humanidade de múltiplos rostos e vozes, de homens e jaguares, de "pessoas" de água, vento e montanha.

Maskarada (figs. 14 e 15) foi idealizada por Suyan de Mattos. Um coletivo composto de 45 artistas do Brasil, Argentina, México, EUA, Itália e Espanha. Alternam-se entre construir e vestir máscaras, publicá-las em um perfil do Instagram, em lives e rituais, em performances e ações. 

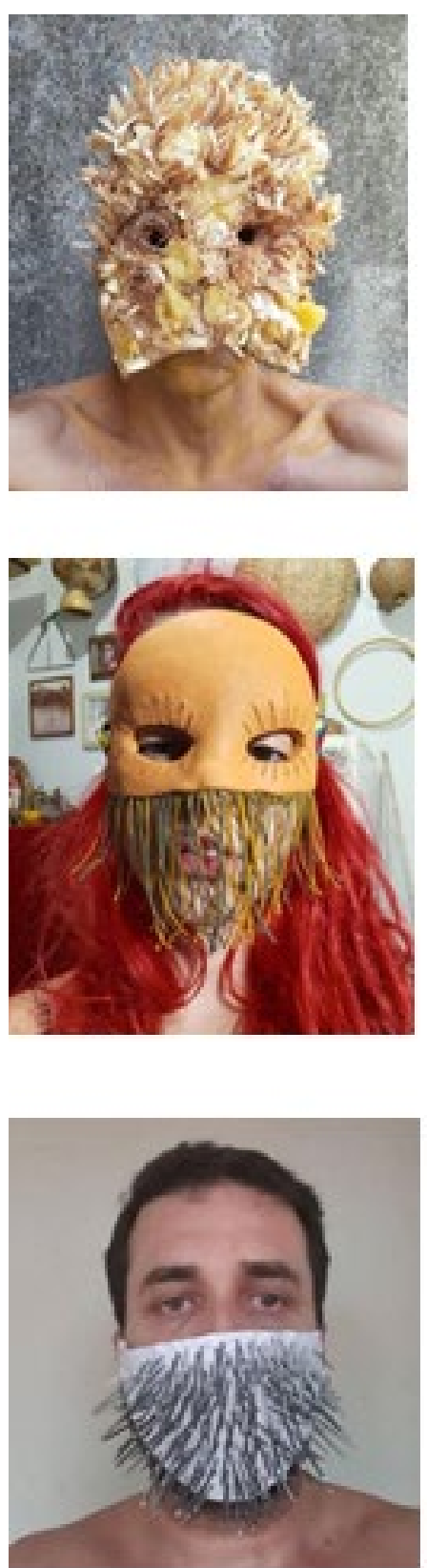

Figura 14

Maskarada: 1 e 2 José Arcanjo;

3 - Eduardo Mariz;

4 - Laura Dorneles;

5 - Suyan de Mattos; 6 -Monica Lóss;

7 - Alexandre Paes; 8 - Clarisse Tarran; 9 - Arthur Scovino; 10 Marilu Cerqueira; 11

- Gabriela Irigoyen; 12 - Lara Ferreira
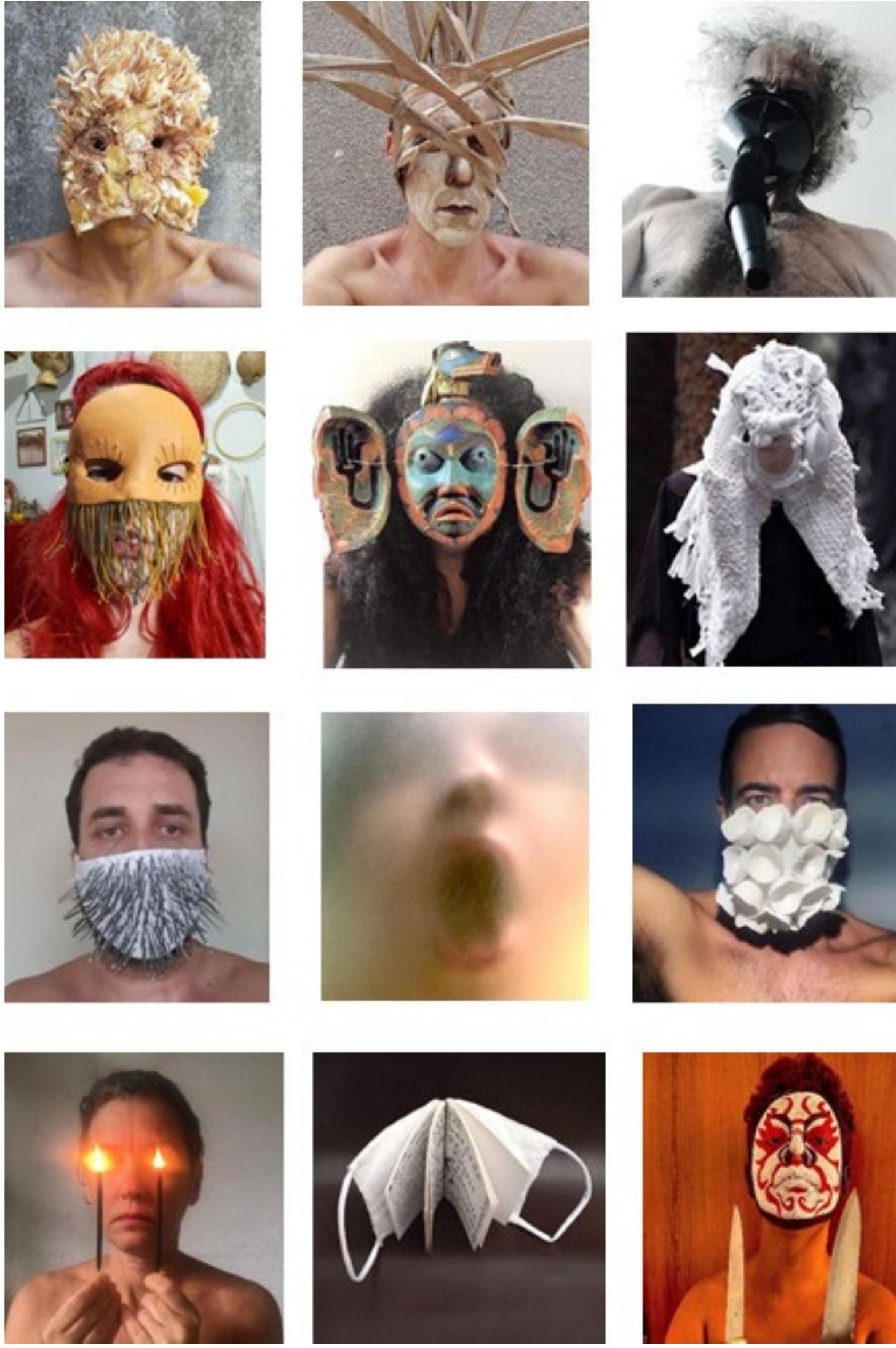
São máscaras arcaicas transfiguradas; híbridos de humanos, animais e plantas; cafuzos de máquina e gente; mestiços de refugos de metais; máscaras de invocação das ancestralidades ameríndias e africanas, de pandemias do passado como a do pássaro da peste negra; máscaras de guerra e festa, de luto e celebração. Vestidas, transformam a mascarada em rituais de afetos e imagens, de transmutação e revolta. Máscaras são como uma força que flutua, como uma intensidade existencial que se confunde com seu movimento corpóreo, como potência de alteridade, como ressoar de vozes, como rostos improváveis e inauditos.

À exclusão da diferença, se confronta a reinvenção dos modos de vida, das subjetividades, do funcionamento do desejo. Ao mal-estar, os corpos respondem com a pulsão vital, com o desejo que busca novas formas de expressar como é afetado pelo mundo e de recriá-lo. O desejo os lança ao fora e recusa a identidade fixa e impermeável, pois a existência é antes uma insuficiência que apela a uma pluralidade de outros, que se transforma incessantemente na relação e no contato com a alteridade. Buscar a reinvenção dos corpos e dos modos de existência pela arte, em variados meios e suportes, em imagens e palavras, em máscaras e danças. Corpos cafuzos, trans, mutiespéscies, corpos "infames" que se rebelam e teimam sobreviver em tempos sombrios e em seus campos de morte e asfixia. Corpos em tensão, como força insubmissa e informe que excede qualquer grilhão, medida ou destino. A arte, a vida, quer persistir com suas muitas vozes, faces e afetos. 

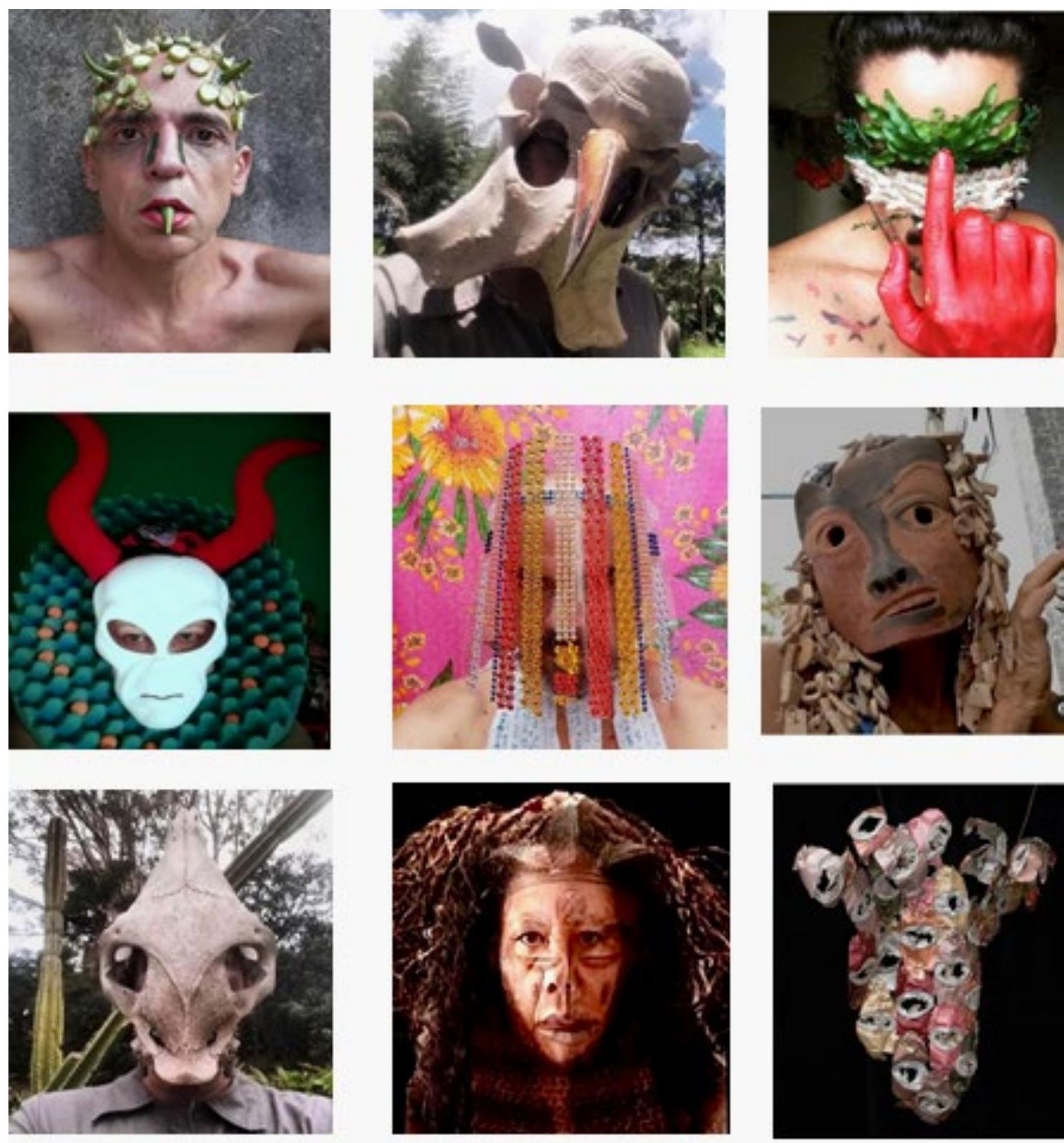

Figura 15 Maskarada: 1 - José Arcanjo; 2 - JABAL; 3 - João Leite; 4 Ângela Alexsander; 5 - Wagner Rossi Campos; 6 - Cris

Cabus; 7 - JABAL; 8 - Suyan de Mattos;

9 -Sandra Lapage; 10 - Lara Ferreira; 11

- Stephanie Zedli; 12 - Alexandre Paes



\section{Referências}

BELTING, Hans. Faces: uma história do rosto. Trad. de Artur Morão. Lisboa: Ymago, 2019.

Por uma antropologia da imagem. In: Concinnitas. Revista do Instituto de Artes da UERJ, v.2, n.8, 2005. Disponível in: https:// www.e-publicacoes.uerj.br/index.php/concinnitas/article/view/55319

DELEUZE, Gilles; GUATTARI, Félix. Micropolítica e segmentaridade (Tradução de Suely Rolnik). In: Mil Platôs volume 3 - capitalismo e esquizofrenia, vol. 3 /v.3.Tradução de Aurélio Guerra Neto et alii. Rio de Janeiro: Ed. 34, 1996 (Coleção TRANS).

Didi-Huberman, Georges. Imagem-matriz. In: Diante do tempo: história da arte e anacronismo das imagens. Trad. de Vera Casa Nova, Márcia Arbex. Belo Horizonte: Editora UFMG, 2015.

DIDI-HUBERMAN, Georges. O rosto e a terra/ onde começa o retrato, onde se ausenta o rosto. In: Porto Arte, Porto Alegre, v.9, p.61-82, 1998.

FOUCAULT, Michel. Em defesa da sociedade: curso no Collège de France (1975-1976). Trad. de Maria Ermantina Galvão. São Paulo: Martins Fontes, 2010.

GINZBURG, Carlo. Medo, reverência, terror: quatro ensaios de iconografia política. Trad. de Federico Carotti, Joana Angélica d'Avila Melo e Júlio Castañon Guimarães. São Paulo: Companhia das letras, 2014.

HOBBES DE MALMESBURY, Thomas. Leviatã ou matéria, forma e poder de um Estado eclesiástico e civil. Trad. de João Paulo Monteiro e Maria Beatriz Nizza da Silva. São Paulo: Nova Cultural, 1988. [Col. Os Pensadores].

KRENAK, Ailton. Ideias para adiar o fim do mundo. São Paulo: Companhia das Letras, 2019.

MBEMBE, Achille. Necropolítica. Trad. de Renata Santini. São Paulo: n-1 edições, 2018.

MONDZAIN, Marie-José. Le Commerce des Regards. Paris: Éditions du Seuil, 2003. 
NANCY, Jean-Luc. Fazer, a poesia. Disponível in: https://www.scielo.br/ pdf/alea/v15n2/10.pdf

SAFATLE, Vladimir. Para além da necropolítica. Disponível in: https:// www.n-1edicoes.org/textos/191.

SCHAEFFER, Jean-Marie. O corpo é imagem. Trad. de Ana Cavalcanti. In: Revista Arte \& Ensaios 16, 2012-01. Disponível in: https://www.ppgav.eba. ufrj.br/wp-content/uploads/2012/01/ae16_Jean-Marie_Schaeffer.pdf

SIMAS, Luiz Antonio; RUFINO, Luiz. A gramática dos tambores. In: Fogo no mato: a ciência encantada das macumbas. RJ: Mórula Editorial, 2019.

VIRILIO, Paul. L'insécurité du territoire. Paris: Galilée, 1976.

Recebido e aceito em 28 de abril de 2021.

Este é um artigo publicado em acesso aberto sob uma licença Creative Commons $(\mathbf{c c}) \mathbf{B r}$ 